\title{
FOOD SECURITY IN NIGERIA: AN OVERVIEW
}

Emmanuel O. Ojo ${ }^{1}(\mathrm{Ph} . \mathrm{D})$ and Peter F. Adebayo ${ }^{2}(\mathrm{Ph} . \mathrm{D})$

\begin{abstract}
No doubt, food is life; hence, food has become an instrument of national power. It is within that imperatival need for food that this paper takes a cursory look at the issue in all its ramifications. The paper with a comprehensive review of Nigeria's agricultural policy noted that much still needs to be done if the crisis in the sector will not escalate more so, in a supposedly democratic dispensation which expectedly should promote the value of welfarism. The paper infers that Nigeria needs to come up with food policy which for now it lacks. What public policy makers pursue is merely an agricultural policy that still suffers enormously from a wide gap between intent and actual practices.
\end{abstract}

Keywords: Food-security, biotechnology, budget, national-power, climatechange.

\section{Introduction}

Nigeria, blessed as it is, with abundant agroecological resources and diversity, has become one of the largest food importers in sub-Saharan Africa

- Idachaba (2009)

The above quotation by Nigeria's renowned agricultural economist epitomizes the central argument of this paper that Nigeria's food situation is

| 1 Associate Professor Email:eojo12000@yahoo.com Cell: 08033822383/07057807714

Department of Political Science, Lagos State University, Lagos State, Nigeria

2 Senior Lecturer_E-mail: peter_adebayo2000@yahoo.com

Department of History P.M.B. 1515 University of Ilorin, Kwara State, Nigeria 
not good enough. Any system where food demand is not sufficiently marched by supply is no doubt one with looming food crisis. Despite pretensions to the contrary, Nigeria is far from being completely food secured. At the global level, somewhere in the world, a child dies of hunger every five seconds, although the planet has more than enough food for all. The United Nations (UN) Secretary General, Ban Kimoon, laid out these sobering statistics as he kickedoff a three day summit on world food security in Rome. "Today, more than one billion people are hungry", he told the assembly leaders. Six million children die of hunger every year, 17,000 every day. Dan Kimoon added that in 2050, the world will need to feed two million more mouths -9.1 billion in all (see, Nigerian Compass, November, 18, 2009:6).

In a perceptive work, Kenneth Dahlberg (1998:24-28) identified four global threats that has significant implications for the food security of cities. First, there are three different types of incipient population explosions: human, livestock and cars. The threats of increasing human numbers and urbanization are clear. Less often considered is the explosion since World War II of livestock numbers - today some 38 percent of the world's grain crop is fed to livestock. Second, there is global warming - an issue beset by uncertainty and confusion. While a few regions may benefit from global warming, the latest projections suggest African agriculture is the most vulnerable, while many agricultural areas in the temperate zones will suffer from more frequent storms, droughts, and floods as well as temperature extremes. Third, the loss of biodiversity is perhaps the greatest long-term threat to global sustainability. The fourth one is the threat of poverty and globalization of injustice. Whatever one understands the sources of this to be, the weak, and the poor (including poor cities and states) are becoming more vulnerable than ever to powerful economic forces and structures. For instance, significantly, after 50 years, average grain prices over the last three years have increased 12 percent a year for wheat, a percent for rice, and 16 percent for maize (see, Dahlberg, 1998:25).

It is in view of the foregoing that attainment of food security is imperative in any country. This is why all developed and developing countries make considerable efforts to increase their food production capacity. But hunger, defined here as a situation in which there is an inadequate quantity of available food; and malnutrition which is indicative of intake of unbalanced diets, have been ravaging most developing countries, severely menacing poor families (Macnamara, 1973:107). Both have also had debilitating effects in the productive capacity of the citizens, impacting negatively on the overall economic development of many countries. The twin problem of hunger and malnutrition is closely linked with poverty. While hunger may be occasioned 
mostly by lack of jobs, or hyper - inflation that causes reduced purchasing power among others, which may be eliminated or reduced with sound management of the national economy, malnutrition is caused by poor diet and has a very long-term devastating effect as people in many poor countries. Medical and anthropometric evidence has shown, for instance, a very close link between malnutrition and infant mortality, poor growth in children as well as reduced adults' immune system to fight some diseases. To be sure, malnutrition saps the working strength of an economy, cripples the mind and body of children and consequently deprives the society of its greatest potential that is, its future productive human resources (Salvative and Dowlins, 1977:61). In contrast, countries that are food-secure do not have this dreadful situation to contend with (Davies, 2009).

Meanwhile, Nigeria is one of the food-deficit countries in sub-saharan Africa although it is arguably better in terms of production than the others. It has also not suffered any major catastrophe that could precipitate scourges of famine, mass hunger and therefore food crisis. This does not in anyway prevent public policy makers from being conscious of avoiding the debilitating impact of food shortages in neighbouring countries which has however made food security become a first order priority of the present Nigerian government (Atinmo and Adeniran, 1999:110). This paper has two major foci. First, it is to evaluate Nigeria's food security situation and second it is to explore food security and diplomacy most especially in a democratic dispensation. To achieve this objective, the paper has been divided into a number of sections. With this introductory overview, the paper proceeds to conceptualizing food security without necessarily being definitional. The third part is an evaluation of Nigeria's food security. Part four is an in-depth review of Nigeria's agricultural policies over the years. The fifth part is on the imperative of food security in Nigeria's nascent democracy. The sixth part dwells on science, technology and food security. While the seventh part also explores the nexus between food security and diplomacy in contemporary states' gamut of interactions. The paper infers that the wide gap between intents and actual practices vis-à-vis Nigeria's food policy and programmes may require a new approach and philosophy if the fate that befell Nigeria's neighbour will not befall the country more so, that the country lacks clear cut food policy. We now proceed to the conceptualization of food security. 


\section{CONCEPTUALISING FOOD SECURITY}

Having presented the general purpose of ... a study, (literature review) brings the reader to date in the pervious research in the area, pointing to general agreements and disagreements among the previous researchers ... Carefully review the studies that led to the acceptance of those ideas ... (Babbie, 1998).

This section of the paper takes off with the above premise as postulated by Babbie (1998). Without necessarily being definitional, we intend to conceptualize food security. This becomes imperative in the sense that it has assumed the status of an "essentially contested concept" (see, Gallie, 1962). Simply because the concept of food security has been used in various ways. Whereas, food security in its most basic form is defined as the access to all people to the food needed for a healthy life at all times (FAO and WHO, 1992 cited in Eide, 1999:3). Though, in a simple language, a country is food-secure when majority of its population have access to food of adequate quantity and quality consistent with decent existence at all times (Reutlinger, 1985:7; Idachaba, 2004:2). What is implied in this definition is that food must be available to the people to an extent that will meet some acceptable level of nutritional standards in terms of a calorie, protein and minerals which the body needs; the possession of the means by the people to acquire (i.e. access) and reasonable continuity and consistency in its supply (Davies, 2009:4). In other words, food security can be taken to mean access by all people at all times to sufficient food for an active, health life (Reutlinger, 1985). Its central elements are: (a) the availability of food and (b) the possession of the ability for its acquisition (Adeoti, 1989:117). Food insecurity on the other hand represents lack of access to enough food and can be either chronic or temporary. In chronic food insecurity, which arises from a lack of resources to produce or acquire food, the diet is persistently inadequate (Adeoti, 1989:117).

It should be noted that availability of food alone does not seem sufficient to explain the attainment of food security in a country. Food can be available in a country because of effective agricultural policy; good harvest in a particular year or massive importation of food; or food handout (aid). Massive food import, particularly by developing countries, usually has negative effect on foreign reserves and causes budgetary hemorrhage (Davies, 2009), while food and which is sometimes used as an economic instrument in the service of political goal of the donor countries (Ikoku, 1980:286), may even discourage 
food production activities in the recipient countries; any country that needs massive food input or food aid before its citizens could feed would have only a short term solution to its food crisis but would not be food-secure for all times because the feeding of the people in that country will be dependent on the willingness and sometimes the ability of the external suppliers to supply. This is not to suggest that every country that has reason(s) to import food lacks food supply. On the contrary, some countries may and do import food to offset production shocks and cover the short-fall in domestic food supplies (Lavy, 1992:126), encourage consumption of some food items or even assist the export trade of a particular target state with which they have bilateral trade agreements. Import of food by such countries may not necessarily be undertaken to solve any severe food shortage problem. To that extent, these countries are not food-insecure.

Food security should not be seen only from the perspective of availability as earlier mentioned either in quantitative or qualitative terms. Food hygiene and safety should also be given important consideration in order to protect the health of the people. Food, for instance, may be available but the source from which the food is produced or processed may be unhygienic or that the chemical substances used to produce or preserve the food may constitute a health hazard. Health and safety consideration therefore becomes important in food production. For instance, given the likely general misuse of chemicals due to illiteracy and crass ignorance, particularly in developing countries, some chemicals used for treating livestock diseases indiscriminate application of pesticides to treat crops diseases or control pest and other agricultural parasites, may be harmful to humans much later after the consumption of the agricultural products (Sinha, 1976:21). In essence, a country should be considered as food-secure when food is not only available in the quantity needed by the population consistent with decent living, but also when the consumption of the food should not pose any health hazard to the citizens (Davies, 2009).

The new thinking in the extant literature on food security not long ago is the nexus between the concept and human rights. On 10 December1948, the United Nations General Assembly proclaimed the Universal Declaration of Human Rights and called it a common standard of achievement for all peoples and all nations. One of these rights is the right to adequate food and to be free from hunger, which is set out in the Universal Declaration (Article 25), in the Covenant on Economic, Social and Cultural Rights (Article 11), in the Convention in the Rights of the Child (Articles 24 and 27), and in numerous other instruments (see, Eide, 1999:2). International human rights law has thus firmly established that everyone has a right to adequate food and a 
fundamental right to be free from hunger. These rights are assumed to be universal, though clearly they are not yet globally enjoyed. While there has been a long process to make these rights universal since 1948, much remains to be done. Eight hundred million human beings around the world suffer from severe malnutrition, for them, food security is non-existent. This represents a severe weakness in existing human rights policy (Eide, 1999). In the words of Jenkins and Scanlan (2001:718), food is the most basic of human needs and is central to the discussion of human rights and social development.

In the same vein, food security has been promoted by the United Nations as the most basic human need and as a central indicator of absolute poverty and physical well being. Food security refers not only to an adequate aggregate supply of food, but also means that "all people at all times have both physical and economic access to basic food". This requires not just enough food to go around. It requires that people have ready access to food (UNDP, 1994:24 also cited in Jenkins and Scanlan, 2001), this is measured using two indicators: (1) food supply is measured as the mean daily per capita supply of calories and protein (FAO 1996) and (2) the child hunger rate is measured by the percentage of children under age 5 who are undernourished (UNDP, 1994). It is in this context that Clover (2003:5) averred that 'no human right has been so frequently and spectacularly violated in recent times as the right to food". Africa which reversed from being a key exporter of agricultural commodities into being a net importer, has the highest percentage of undernourished people and has shown less progress on reducing the prevalence of undernourishment in the last 30 years. Chronic food insecurity now affects some $28 \%$ of the population that is nearly 200 million people who are suffering from malnutrition. Acute food insecurity in 2003 is affecting 38 million people in Africa who are facing outright risk of famine with 24,000 dying from hunger daily. Famines are the most visible and extreme manifestation of acute food insecurity. Of the 39 countries worldwide that faced food emergencies at the beginning of 2003, 25 are found in Africa.

It is vital to add that Amartya Sen (cited in Clover, 2003) has been credited with initiating the paradigm shift in the early 1980s that brought focus to the issue of access and entitlement to food. Food insecurity is no longer seen simply as a failure of agriculture to produce sufficient food at the national level, but instead as a failure of livelihoods to guarantee access to sufficient food at the household level. Today, most common definition begin with individual entitlement, though recognizing the complex inter-linkages between the individual, the household, the community, the nation and the international community (see, Clover, 2003:7). In the 1996 Rome declaration on world food security, food security is defined as: 
food that is available at all times, to which all persons have means of access, there is nutritionally adequate in terms of quantity, quality and variety, and is acceptable within the given culture (cited in Clover, 2003:7).

Availability, access and affordability are all elements of food security complex issues that encompass a wide range of interrelated economic, social and political factors - internal and external which challenge Africa's ability to address food security.

In a perceptive work, Menghestab Haile (2005: 2169) identified a number of factors that are responsible for the precarious food insecurity, in Africa. They are: low agricultural productivity, lack of agricultural policies, poor infrastructure and high - transport costs, lack of appropriate marketing strategies, frequent extreme weather events, high - disease burden including HIV/AIDS, weak financial support systems, lack of safety net systems and political conflicts. The greatest challenge facing food security in Africa too for Smith (1998:207) is poverty. We now proceed to the evaluation of Nigeria's food security situation.

\section{EVALUATING NIGERIA'S FOOD SECURITY}

In the 40s and early 50s, Nigeria did not have to contend with the problem of food insecurity. The system was able to feed her citizens and at the same time export the surplus food items. Every regions of the country specialized in the production of one or two major crops, whether food or cash crops, and together the country was relatively self-sufficient in food production. Nigeria had the groundnut pyramids in the North, the cocoa maintains in the west, oil palm and kernel heaps in the East and the rubber plantation in the mid-west (see, Tell, August 3, 2009:2). But when oil was discovered in 1956 and exportation of it started in 1958, things started changing gradually, and later furiously. It was like declaring holiday for hoes and machetes. As oil prices went up, interest in agriculture waned which marked the beginning of decline into the abyss as a polity.

The consequential effect of the decline like some countries of the world, the nation's economy is feeling the brunt of the rising cost of food items, especially the rise in the prices of staple foods. Significantly, the price of rice has increased by over 100 per cent since 2006. It is instructive to note that Nigeria requires 2.5 million metric tones of rice annually while local rice production is less than half a million metric tones per year (Teel, May 5, 
2008:23). With these figures as released by Minister of Agriculture and Water Resources, Nigeria is short of two million tones of rice, which it has to source from other countries. It is estimated that Nigeria spent a whopping $\$ 2$ billion dollars importing about six million tones of wheat, $\$ 750$ million on rice $\$ 700$ million on sugar and $\$ 500$ million on milk and other dairy products (Tell, May 5, 2008:23). As things stand now, Nigeria is likely to spend even more. With the global rise in food prices, the United Nations Food Security Information Note, (FOSIN), of November 2007 showed that "market tensions manifest, in part, through price increases would be most acutely felt by vulnerable households, where difficulties in accessing cereals would lead to localized food security problems (see Tell, May 5, 2008:23).

Beyond high prices of staple food items in Nigeria, drought and political situation in neightbouring countries like Chad, Cameroun and Niger seem to pose a threat to a state like Borno as they rely on the state for their food supplies. Another problem according to the Ministry of Agriculture and Water Resources, responsible for the food crisis in Nigeria is not unconnected with the fact that "Nigeria's agriculture is mainly rain-fed and she has not taken full advantage of its irrigation potential estimated between two and 2.5 million hectares". The area under irrigation is officially estimated at about 220,000 hectares or less than one per cent of the total areas under crops. The contribution of irrigated agriculture to crop production is, therefore, very small (see, Tell, May 5, 2008).

In contrast, while drought presents a major problem for the affordability and availability of food items, excessive rain has also contributed significantly to the current hike in food prices. Statistics from Gombe State alone as compiled by Gombe State Emergency Management Agency (GSEMA) show that about 999 farmlands in the state were affected by floods which destroyed yams, maize, vegetable, sugarcane and cassava farms in 2007 (Tell, May 5, 2008), when data from other states are added together, no doubt, the ripple effect becomes staggering.

Whereas, climatic conditions favour the rising food prices, the deficiencies in the delivery of farm inputs also come to the fore as a major challenge to farmers. Another factor is the low usage of fertilizers, occasioned by using the poor level of availability resulting in low crop yield. The Ministry of Agriculture and Water Resources has disclosed that current use of fertilizer is about 1,000,000 metric tones per annum, while the projected demand estimate is 3.7 million metric tones. While the "average worldwide rate is $93 \mathrm{~kg}$ per hectare of NPK, the rate for Nigeria is around 13kg per hectare" (Tell, May, 5, 2008). 
Indeed, these are challenges threatening the food security of nations. While the federal government has instructed that the strategic grains reserve be released to ameliorate the scarcity and rising prices, Abba Ruma, Nigeria's Agriculture and Water Resources Minister, has indicated that even this may have its shortcomings. In the sense that this short-term solution may not work because the reserves do not have the essential food items such as rice, wheat and sugar, whose prices are increasing in the global market steadily (Tell, May $5,2008)$. According to the minister, 65 per cent of the Nigerian population is suffering from lack of food security, adding that 40 per cent of children under five are stunted and 25 per cent are under weight. In fact the poverty situation of the country is brought home by the 2006 Global Index of Hunger which ranked Nigeria as the $20^{\text {th }}$ poverty-stricken nation.

\section{A REVIEW OF NIGERIA'S AGRICULTURAL POLICIES}

The Nigerian government is not taking things for granted. All efforts directed at restoring agriculture to its former status before the oil boom in the national economy in terms of its higher contribution to the Gross Domestic Product (GDP), could be regarded as evidence of increased concern for and commitment to food security. In desperation, the Gen. Yakubu Gowon military government embarked on a gargantuan importation of rice in the early 1970s to stave off hunger. But Nigerian ports did not have the facility to handle the huge importation of what came to be called the Rice Amada. The ports were choked by rice and a decogestation committee had to be set up (see, Ekpu, 2009:12). At the end of the day, massive importation of rice could not tackle the long term problem of food security; rather than a profound agricultural policy shortly after the civil war. Whereas, Nigerians suggested to the government then that the over bloated army which became redundant after the civil war could be drafted to the farm to boost agricultural production. This poliy option was discarded simply for security reason.

In 1976, General Olusegun Obasanjo government started what was known as Operation Feed the Nation, (OFN). This was intended to be some kind of agricultural revolution in which everyone was asked to be involved to plant something, anything, anywhere. Those who didn't have farms as gardens resulted to flower pot farming. However, for various reasons, these efforts did not produce the bumper harvest that was expected and cynical Nigerians nicknamed the programme Operation Fool the Nation (Ekpu, 2009:12).

When Sheu Shagari took over as President in 1979, he embarked on a mere change of name. He called his own initiative Green Revolution without any significant change in conception, content or context of the policy. Thus, 
the programme could not make any appreciable impact. Not only that his government was weighed down by corruption that it could not achieve much in all fronts. Then came General Ibrahim Babangida's Directorate of Food, Roads and Rural Infrastructure, DFRRI in 1985. It was supposed to be a comprehensive, integrated programme for massive food production and rural transformation. On paper, it was great but in actual practice, the programme was invested with massive corruption and eventually frustration.

However, with the advent of civilian administration in 1999 greater attention was given to food production. The Nigerian Minister for Agriculture, publicly restated government's commitment to combat hunger and malnutrition by providing adequate food for the people and ensures food security for all. To achieve this goal therefore, a number of what he called food security initiatives were launched (see, Bello, 2004:1-6). They include:

1. Special Programme for Food Security (SPFS): This is a programme by which the government sought the assistance of the Food and Agriculture Organization (FAO), in disseminating information on proven and accessible technologies to 109 farming communities across the country to enhance food production and substantially increase income levels of the farmers.

2. Root and Tuber Expansion Programme: This is an agricultural programme supported by International Fund for Agricultural Development (IFAD), which made available to farmers the necessary information on improved processing technology and expansion technique for cassava and cassava products.

3. Fadama Development Project: The Fadama project is for ensuring all-season farming through large scale irrigation system or naturally flooded areas (Fadama) of a number of crops, plants, fruits and vegetables.

4. Community-based agricultural and rural development schemes: This comes under different names such as farm settlement or back-to-land programmes. In this type of schemes the participants who are usually men, are encouraged by the government to take to farming by providing them with material and financial support.

5. Provision of infrastructures: Such as linking up the rural areas through new access roads and grading the old ones; supplying energy through rural electrification; distributing farm inputs like seedlings and fertilizer; selling or leasing tractors and harvesters to farmers to encourage mechanized farming and providing improved 
storage facilities to reduce post-harvest loss of agricultural products, put at between 25 and 30 percent (V anguard, October 27, 2004).

6. In collaboration with the United States, the government commissioned the American-based International Centre for Soil Fertility and Agricultural Development (ICSFAD), to study the problems militating against increased agricultural production in the country. The main objective here is to assess the soil type and use the result to determine the appropriate type of fertilizer that would be used by the farmers.

7. Policy instrument and direction by which the government (a) banned, among other items, the importation of some agricultural products. The effect of this ban is said to have "unleashed boundless productive energy in the areas of livestock production and agriculture" (see Presidential National Day Broadcast, Nigerian Tribune, October 1, 2004); (b) sold fertilizer to farmers at subsidized rate and (c) facilitated increased investment in agriculture by strengthening the financial capacity of state-owned agricultural banks to grant soft-loans, and pleading with the private commercial banks to extend low-interest loan facilities to large-scale and smallscale farmers. The plea has been largely ignored by the commercial banks probably because of the perceived risk in agricultural financing and the negative consequences of volatile agricultural market (Larson et. al., 2004:199-250).

The programmes, policy instruments and policy direction enumerated above are clear indications of government's interest in and commitment to, increased food production. According to the government (NEEDS Document, 2001:88), the numerous initiatives are expected ceteris paribus to:

Provide incentives for private sector participation in the agricultural sector, foster effective linkage with the industrial sector; add value to agricultural produce through processing for export, create more agricultural and rural employment opportunities; increase the income of farmers; reduce drastically the rising trend in food import and ultimately achieve food security (see also Davies, 2009:9)

There are, in fact, some euphoric claims from government agencies and officials that the policies and programmes are already yielding desired results because the agricultural sector has recorded unprecedented annual growth rate of seven percent $(7 \%)$; that the strategic grains reserve has reached 150,000 
tons, and still rising. It has also been said that increased food production has encouraged the World Food Programme to contemplate the establishment of an office in Nigeria from where it would obtain food for other African countries in need (see Presidential National Day Broadcast, Nigerian Tribune, October 1, 2004). However, the situation on the ground out rightly negates this claim of super success by the government.

One major policy that deserves comment during the administration of President Olusegun Obasanjo between 1999 and 2007 is the 'cassava initiative'. The policy was to promote exportation and increased productivity. This policy resulted into glut in cassava production. But the 2003 initiative in rice by the same Obasanjo administration did not yield as much result. There was no sustainable back-up to the presidential initiative on rice. Out of the N182.2 billion Naira earmarked for the programme, only N5 billion Naira was released as take-off grant (see, Tell, May 5, 2008:25). Not only that the glut in cassava production eventually robs the state of low price as a result of massive exportation of the produce.

In the same vein, the state of hunger in the country is worsened by the neglect of the agricultural sector. It is instructive to note that over the years, the sector has not received up to 10 per cent allocation in federal budget which is the minimum requirement according to Maputo Declaration of sufficient food production. The highest the sector has received is about seven per cent in 2008 budget (Newswatch, May 5, 2008:27). Up to 2007, budgetary provision to agriculture was three per cent. The greatest challenge in achieving food security in Nigeria, no doubt, has been inadequate funding. The league effect of the underfunding of agricultural sector in the federal budget has always been the unpalatable massive importation of food items. For instance, Nigeria spent $\$ 2.85$ billion dollars on the importation of various food items as at 2006 . A breakdown of this figure showed Nigeria imported 36 per cent of its rice need costing \$267 million dollars, sugar, 99 per cent costing $\$ 1$ billion, wheat 99 per cent totaling $\$ 1$ billion dollars and tomatoes 14 per cent costing $\$ 50$ million dollars. Fish import is 66 per cent per consumption costing $\$ 500$ million dollars (see Newswatch, May 5, 2008:27).

Over the years, the federal government has got help from different international bodies such as the World Bank, Food and Agricultural Organisation FAO, United States Agency for International Development USAID, and International Fund for Agricultural Development, IFAD, to boost its agriculture to feed the nation. FAO has about 20 programmes and projects in agriculture in Nigeria. There is the national special programme for food security whose second phase took off in 2008. The amount slated for this programme is $\$ 364$ million. Also the World Bank has Fadama programme 
which is going into its third phase. The bank since the 90s has spent about $\$ 417$ million dollars to boost agriculture in the country.

From the foregoing, successive administrations have been trying to ameliorate the food security problem. But the wide gap between intents and actual practices has always been the bane of Nigeria's agricultural policies. At a special colloquium organized by the Newswatch Communications Limited in partnership with Adamawa, Benue, Delta, Imo and Edo States with the theme "Agriculture and Food Crisis in Nigeria", a number of problems have been identified inhibiting effectiveness of agricultural policies. Some of them are:

(a) Policy somersaults, that is, the frequent changes of policies on agriculture as one government replaces another. On each occasion, Nigeria has always had to start afresh.

(b) Agriculture is still regarded as a vocation for the illiterates in the rural areas who have nothing better to do. The big farmers politicians, retired generals and businessmen - engage largely in crops or animals cultivation that are not common staples. They have pineapple plantations, ostrich and other exotic farms that add nothing to our quest for food security. The lack of mechanized farming is certainly something to worry about.

(c) No one knows the impact of the agriculture credit scheme with the banks and that is precisely because the impact must be very little.

(d) Corruption which has been a serious problem in the country has not left agriculture untouched. The river basins, dams, silos and fertilizer contracts have, over the years, been dripping with corruption. How can agriculture grow if corruption is stymieing its growth?

(e) Many women are small scale farmers; in fact, they form the bulk of the farming constituency, but hardly are they consulted on policy and or gender issues that affect agriculture, land ownership and or usage. Such gender insensitivity is pervasive.

(f) Farmers are not well remunerated for their products. Nigeria produces the largest quantities of cassava, yams and cocoyam in the world, but the impact on their income is minimal and this tends to discourage them.

(g) Fertilizer is an important ingredient for improved yield but Nigeria plays politics with it. The people who get fertilizer allocations hardly have farms, they only have party cards. In 1993/94 cropping seasons, government provided one million metric tones of fertilizer. But by 1997, subsidy on fertilizer was removed and fertilizer 
consumption dropped to 200,000 metric tones, the lowest ever, thus worsening the food situation.

(h) In 2008, the federal government allocated N89.95 billion for agriculture and water resources. Apparently, not much of that money was released which is why there is a lot of controversy about budgets that are approved but hardly implemented in Nigeria.

(i) Climate change is threatening agricultural production through higher and more variable temperatures, changes in precipitation patterns and increased occurrences of extreme, events such as flood and drought. Besides, the developed countries have fashioned out a response to global warming by using biotechnology to produce biofuel, the so-called green fuel. They are producing biofuel from some food items which will do two things: lead to a reduction of demand for oil and an increase in food shortage (see, Ekpu, 2009:13).

\section{IMPERATIVE OF FOOD SECURITY IN NIGERIA'S NASCENT DEMOCRACY}

In the preceding section, we have comprehensively addressed Nigeria's agricultural policy along with the accompanying pitfalls. But in the extant literature, there is a wide difference between food policy and agric policy. While agricultural policy is targeted at an expanded food production, food policy has as its goal consideration for minimum multinational standards that will guarantee food security. While expansive agricultural policy is being pushed, there is also the need for a national food policy which seeks to assure all citizens access to food supply that is reasonably priced, relatively safe, adequate in quantity and nutrition (Claffey and Stucker, 1982:50; Nyangito, 1999:112). Presently, Nigeria has no food policy perhaps because there is little appreciation of its contemporary role to agricultural system and practices to promote relative self-sufficiency in food production. To put the matter in perspective, a food policy properly formulated will encompass diet policy that shows for example, the relationship of good diet with good living as well as casual link between inappropriate or insufficient diet and major and common debilitating diseases. With the current knowledge of human nutrition, a food policy will be guided by what the human body requires and which particular food items provide it, all of which are pre-requisites for effective food choices by the people. 
Furthermore, a food policy, unlike agricultural policy, should stipulate safety guideline for food production in the growing food industry, it will crystallize in food safety regulations such as the minimum requirements of basic nutrients that must be present in the food, the conditions under which the food is produced, its packaging and even the advertisement to promote the consumption of the food. Similarly, safety guidelines embedded in food policy should prohibit very harmful practices that may occur in the dairy industry and meat processing factories, as well as the use of carcinogenic food additives and food enhancer that are routinely used by bakers to preserve food or improve its taste (Davies, 2009).

Pesticides, therapeutic drugs and chronically compounded feeds for crop production and improved nutrition for livestock respectively are some of the inputs which experts in agriculture regularly advise and encourage farmers to use while the government sometimes makes them available at subsidized price. But the manufacture, distribution and the application of these agrochemicals can hardly be effectively monitored or controlled without first formulating a good food policy that incorporates safety concerns (Oniang'o and Allotey, 1999:267-267).

What this tantamount to is that the goal of food security will remain unattainable if all that matters to the government is simply making food available in the quantity desired by the people but its consumption is capable of causing the consumers all sorts of ailments, then that country cannot be listed among those that have achieved food security. It is against this background that National Food and Drug Administration and Control (NAFDAC) was established not long ago. However, much as this agency is working hard to be effective in preventing food poisoning and fake drugs, there are a number of reasons why it has not been able to achieve much viz:

(a) its emphasis in terms of its operations and its laboratory facilities has been in ridding the country of fake, substandard and expired drugs, manufactured in or imported into the country;

(b) it is not proactive enough in beaming its search light in the production, sale and distribution of foods as it tirelessly add commendably does on fake and expired drugs; and

(c) its activities overlap with those of the Standard Organization of Nigeria (SON) another regulatory agency, empowered to set standard for all consumer products, including food, drugs, cosmetics, tyres, cables etc. 
Thus, it is imperative that Nigeria gets a comprehensive food policy that focuses on quality rather than quantity. This may go a long way in boosting life expectancy.

\section{Science, Technology and Food Security}

In Africa, Asia, Latin America and other third world countries, Nigeria inclusive, a deterioration in technology or ecology, which lower outputs from given input has long been identified as one of the reasons for poor agricultural production performance (Collier, 1988:764). It is equally important to note that indigenous techniques like crop rotation and other cultural farming practices which have been used to preserve the soil structure and its fecundity do not seem to be adequate or even relevant in the present efforts to boast food production in most developing countries. It is for this reason that the use of chemical and organic fertilizer has been widely promoted in Nigeria, while its rate is even heavily subsidized by the State, despite the awareness of the corruption that is associated with its procurement and distribution (Idachaba, 2004:23). Government intervention to increase food production through technical and economic assistance to the small-scale farmers for land improvement schemes is therefore, not a misallocation of resources as some people have suggested (see, Davies, 2009). It is, in fact, a necessity because viewed from macro-economic perspective; this kind of intervention cannot be left to market forces in the present circumstances. There is thus the need for the government to sustain the intervention.

Not only that, threat to the attainment of food security in Nigeria also comes from the unresolved issue of the safety of genetically modified foods made possible through agricultural biotechnology. Today, biotechnology represents a scientific advance in agriculture with far reaching potentials in increasing food production in an environmentally sustainable manner. Agricultural biotechnology includes using genetics to modify crops and plants to produce more nutritious food, cloning of livestock; tissue culture technique and genetic engineering. Apart from its potential to produce higher yields the one of biotechnology gives shorter gestation and maturity periods to crops, plants and livestock as well as will continue to use biotechnology to produce genetically modified foods (Ndiritu and Wambuguli, 1999:247). Parts of these foods are sold and sometimes given as food aid to developing countries, despite safety concerns raised by some anti-biotechnology campaigners in EU countries against genetically modified foods produced in the United States (The Punch, August 23, 2002). 
Nigerian government has embraced the idea of using biotechnology to boost food production as a pre-condition for food security. It established the National Biotechnology Development Agency at Abuja (Federal Capital Territory) setting aside the sum of 26 million naira (about $\$ 185,000$ ) to be invested in the project, and specifically mandating the Institute of Agriculture Research, Ahmadu Bello University, Zaria, to apply biotechnology for the improvement of farming systems for various crops such as Sorghum, maize, cowpea, cotton and sunflower (see, Vanguard, February 16, 2005).

Furthermore, Nigerian agricultural scientists have been very enthusiastic in advancing the frontier of knowledge in biotechnology. They have been making efforts to assure the people that genetically modified foods do not pose any higher risk to consumers than conventionally cultivated crops, and have been calling on the government to allocate more research funds to enhance the application of biotechnology in agriculture to optimize yield potentials (The Punch, December 9, 2004; Akinyosoye, 2007).

The positive disposition of the government and the enthusiasm of the scientists notwithstanding, there are still obstacles to be overcome before full advantage is taken of scientific information in biotechnology in agriculture. First, the amount set aside for investment in the project is grossly inadequate. While it appears to make economic sense to invite the private sector participation in biotechnology research as the government seems to be doing at the moment, it must, however, be borne in mind that majority of the companies that have the financial capability to go into such venture are foreign-owned and are most unlikely to consider in a viable investment option to venture into purely local agricultural research endeavour. Second, the quality and the effectiveness of extension services needed to increase the awareness of the peasant farmers of the potentials of biotechnology are still low and need to be upgraded. Not only that, the mass media most especially, electronic media (radio in particular) have a role to play in educating rural farmers in their local language and dialects on the associated problems vis-à-vis abuse of agrochemicals. Finally, there are still unwarranted public fears to contend with in the safety of genetically modified foods, stemming from scare-stories, reinforced by superstition and crash ignorance, of the danger in the consumption of genetically modified foods. The incontrovertible fact is that without the help of agricultural biotechnology, success in food security will continue to elude Nigeria (Davies, 2009:16).

\section{Food Security and Diplomacy}

Food no doubt is a veritable weapon used in foreign policy implementation. As posited by Marshall (1954:14-19), "foreign policy of states take form in the course of actions undertaken by authority of states which are 
intended to affect situations beyond the span of their jurisdictions". For Holsti, 1974:101), "it is the actions or ideas designed by policy makers to solve a problem or promote some changes in the environment, that is, in the policies, attitudes, or actions, of another state(s) (also cited in Ojo, 2004:51). Hence, it is worth paying attention to one rather important detail. All population is divided into three groups: enemy, neutral and friendly. As the definition implies, this concerns "foreign countries". (Mshvenieradze, 1985:218). No doubt propaganda as an instrument of foreign policy implementation has three aims of which two are ancillary and one is the main. Essentially these aims are: (a) to distinguish between the three groups; (b) as far as possible to "reshuffle" the population, enlarging the "friendly": groups or at least the "neutral" groups; (c) to suppress the will to resist in the groups defined as "enemy" (Mshvenieradze, 19085:219). Thus, states have been suspected using food for the aforementioned purposes both during war and peace situations. This is not unconnected with the fact that few states are self-sufficient in food supply, nations with surplus export to other nations with great needs either in terms of international trade or aid. But this is a function of the aforementioned categorization of states/population. This is so for two reasons. First, food is life, hence food is an instrument of national power and second, food is used to achieve political ends, because if people are well fed, they would be able ready to contribute to the effective implementation of government policies (Bamisaye, 1987:453). No doubt food has become a new form of weapon in international relations. Expectedly, governments may use food resources in international diplomacy for two purposes viz: to influence international food markets, and secondly to influence international economic and political relationships beyond food markets.

Moreover, a hungry and unenlightened nation is a weak one while any region subject to famine or starvation is an insecure one no matter how vast and populated it is. Such a region will continue to be constantly under threats and be exposed to external penetration either by ways of aids, relief materials or other forms of assistance presumably put together to alleviate the suffering of the people. It is perhaps in realizing all the above mentioned facts that now made every country to place great emphasis on self-sufficiency in food production. The summation of this deduction so far, is that, food as it was is still and will continue to be a weapon of international and domestic politics (Bamisaye, 1987:453).

It will be recalled that during colonialism, Nigeria's food situation was altered to suit their purposes. The emphasis of the colonial food policy was in food in relation to health rather than in food production. The policy thrust consisted of improvement of the quality of food consumed by the introduction 
of new food crops to supplement traditional staples. Such food crops include rice and potatoes, which were richer in energy and proteins especially to the South and the Middle Belt areas. Also, introduction of new strains of cowpeas and soya beans cum the encouragement of their production and consumption. There was also a major campaign in the North for the planting of fruit trees such as mangoes, quavers and citrus trees among others (Ikpe, 2003:218-219).

During the Nigeria's agonizing 30-month civil war between 1967-1970, food was used as weapon of war. Federal government truncated food supply to the war torn area, which led to malnutrition. One of the major signs of malnutrition was Kwashiorkor, a protein deficiency disease which was widespread during the period. By the end of the war, there was widespread starvation in which many thousands of people lost their lives (Ibid.). Starvation in Nigeria/Biafra attracted international attention. After a lot of politicking and diplomacy, there emerged the first international relieve effort in Africa (cited in Ikpe, 2003:226). Through the relied activities of international bodies, different types of European foods were brought into the country and became available to a larger number of people such foods included, rice, milk, wheat flour, assorted kinds of canned foods and beverages. Gradually, many people developed a taste for these foods, which before the war, were only available and demanded by the elite (Ikpe, 2003).

Nevertheless, another dimension to food diplomacy vis-à-vis cultural imperialism via food consumption and taste is the exposure of Nigerians to external food economy and food culture beyond the importation of food stuffs. In the 1990s, this led to the emergence of 'Fast Food Culture (FFC). Now, there are many of such fast food restaurants including Mr. Biggs, Sweet Sensations, Tantalizers and a host of others which now litters the urban centres. Though, the nutritional qualities of these fast foods are still debatable. The unintended consequence of the development is that Nigerian foods become less appealing to the youths who now perceive foreign taste as status symbols. Associated with this altered cultural values vis-à-vis food consumption is the rampant disease like diabetes which was not as prevalent in the past.

Finally, a country that relies heavily on food importation may be taking big risk in terms of unfavourable balance of trade to her disadvantage. For instance, presently Nigeria relies heavily in parboil rice from Thailand with the accompanying balance of trade deficit. Not only that, recently Nigerian newspapers raised alarm over food poisoning associated with imported apples. According to media reports, so many people were hospitalized in Lagos - the commercial hub of Nigeria - for taking apple. For some months Nigerians were very cautious in taking apple. If the apple-producing country were to be 
enemy of Nigeria and the Thailand rice producer too, via food poisoning the population of the country could be decimated. During the cold war, both the Eastern and Western blocs of the divide were as much as possible food sustaining for fear of using food as instrument of warfare rather than mere propaganda and diplomacy. This section of the paper has glaringly demonstrated how potent food may be in international relations and diplomacy

\section{Concluding Remarks}

No doubt, one of the major objectives Nigerian state must pursue in this nascent democratic era is food security. A country that cannot formulate and effectively implement agricultural and food policies may find it difficult to use the citizens as catalyst for sustainable democracy. More so, the very survival of the state is linked to the ability of its economy to meet the material demands of both people and government. In the words of Daniel Wit (1953:9), "welfare constitutes a third objective of modern government". Any government be it democratic or dictatorial that makes her citizens go hungry will definitely run into trouble. One must turn to the feudalistic and hence mediaeval, states of the Arab world or of portions of South-east Asia to discover any approximation of the non-welfare government in the contemporary world. That welfare is an objective of all modern nation states is a fact comparable to their common pursuit of national economic health. Welfare activity is engaged in, because people the world over, demand it of their governments. In essence, food is an essential component of welfarism. The greatest recommendation of this paper to avoid recapitulation is that public policy makers must as a matter of urgency see food as component of welfarism and as such develop sufficient political will to achieve (i) increased food production; (ii) evolve food policy and (iii) eventually attain food security for all.

\section{References}

Adeoti, J.A. (1989), "Economic Crisis in Developing Countries: The Food Dimension", Ilorin Journal of Business and Social Sciences, Vol. 1.

Akinyosoye, F. (2007), Microbial Biotechnology: A Tovs for Global Development, Inaugural Lecture, Federal University of Technology, Akure.

Atinmo, T. and Adeniran, T. (1999), "Policy Failure in the Search for Food Security in Nigeria" in Ogunrinade, A., Oniangio, R. and May, J. (eds), Not by Bread Alone: Food Security and Governance in Africa, South Africa, Toda, Institute for Global Peace and Policy Research. 
Babbie, E. (1998), The Practice of Social Research, Wadswroth Publishing Company, Balmont, CA A17.

Bamisaye, O.A. (1987), "Food Crisis and its Implication in Political Transformation of Nigeria since Independence", in Stephen, O. Olugbemi (ed), Alternative Political Futures for Nigeria, A publication of the Nigerian Political Publication, Lagos, Nigeria.

Bello, A. (2004), Keynote Address presented by the Honourable Minister for Agriculture and Rural Development, at the ARMTI Annual Lecture, Ilorin, March 24, 2004.

Claffey, B. and Stucker, T. (1982), "Food Stamp Program" in Hadwiger, D. and Talbot, R. (eds), Food Policy and Farm Programs, New York, The Academy of Political Science.

Clover, J. (2003), Food Security in Sub-saharan Africa, African Security Review, Vol. 12, No.1.

Dahlbrg, K.A. (1998), "The Global Threat to Food Security", Urban Age, Winter, Vol. 5, No.3.

Davies, A.E. (2009), "Food Security Initiatives in Nigeria: Prospects and Challenges", Monograph, Department of Political Science, University of Ilorin, Nigeria.

Eide, A. (1999), "Globalization, Universalization and the Human Right to Adequate Food", in Ogunrinade A, Oniango, R. and May, J. (eds), Not by Bread Alone", Food Security and Governance in Africa, a publication of Toda Institute for Global Peace and Policy Research, South Africa, ABC Press.

Ekpu, R. (2009), "A Harvest of Hunger", in Special Colloquium Edition, Newswatch, (August 3), Lagos.

Gallie, W.B. (1962), Essentially Contested Concepts, in Max Black (ed), The Importance of Language, New Jersey, Prentice Hall.

Haile, M. (2005), "Weather Patterns, Food Security and Humanitarian response in sub-saharan Africa", in philosophical transactions. Biological Sciences, Vol. 360, No. 1463, published online by The Royal Society.

Holsti, K.J. (1974), International Politics: A Framework for Analysis, Prentice Hall International Inc., London.

Idachaba, F. (2004), "Food Security in Nigeria Challenges under Democratic Dispensation", paper presented at ARMTI, Ilorin, Kwara State (March 24).

Idachaba, F.S. (2009), "The Looming Food Crisis", Newswatch, Lagos, (August 3), Special Colloquium Edition.

Ikpe, E.B. (2003), "Food Politics and Diplomacy in Nigeria in the 20th Century", in Yomi Akinyeye (ed), Nigeria and the Wider World in the 20th Century (Essays in honour of Prof. Akinjide Osuntokun, Davidson Press, Ibadan.

Jenkins, J.C., and Scanlan, S.J. (2001), "Food Security in Less Developed Countries, 1970 to 1990", American Sociological Review, Vol. 66 (Oct.).

Larson, O., Anderson, J. and Vargingis, P. (2004), Policies in Managing Risk in Agricultural Markets, The World Bank Research Observer, Vol. 19. 
Macnamara, R. (1973), One Hundred Countries: Two Billion People". The Dimensions of Development, New York: Praeger.

Marshall, C.B. (1984), The Limits of Foreign Policy, Holt Rinehart and Winston.

Mshvenieradze, V. (1985), Political Reality and Political Consciousness, (English Translation), Progress Publishers, Moscow, Russia.

National Economic Empowerment and Development Strategy (NEEDS), (2004) Abuja, National Planning Commission.

National Economic Empowerment and Development Strategy (NEEDS), (2004), Abuja. A publication of National Planning Commission.

Ndiritu, C. and Wambuguh, L. (1999), "The Role of New Technologies in enhancing food security in Africa", in Ogunrinade, A., Oniang'o, R. and May, J. (eds), Not by Bread Alone: Food Security and Governance in Africa, South Africa, Toda Institute for Global Peace and Policy Research.

Nyaugito, H. (1999), Food Policy and the Impact on Food Security", in Ogunrinde, A., Oniang'o, R. and May, J. (eds), Not By Bread Alone. Food Security and Governance, Society Africa: Tore Institute for Global Peace and Policy Research.

Ojo, E.O. (2004), "Public Opinion and the Conduct of Nigeria's Foreign Policy: Two Selected case studies", The Nigerian Journal of the Social Sciences, Vol. 3, No.1.

Oniang'o, R. and Allotey, J. (1989), "Food Safety and the Role of Government" in Ogunrinde, A., Oniang'o, R. and May, J. (eds), Not by Bread Alone: Food Security and Governance, South Africa: 2009 Institute for Global Peace and Policy Research.

Rentlinger, S. (1983), "Food Security and Poverty in LDCS", Finance and Development, Vol. 22, Nos. 7-11.

Salvatore, D. and Dowling, E. (1977), Theory and Problems of Development Economics, New York: McGraw-Hill.

Smith, D.W. (1998), "Urban Food Systems and the Poor in Developing Countries", Transactions of the Institute of British Geographers, New Series, Vol. 23, No. 2, published by Blackwell publishing on behalf of the The Royal Geographical Society.

United Nations Development Programme (UNDP) (1994), Human Development Report 1994, New York: Oxford University Press.

Wit, D. (1953), Comparative Political Institutions: A Study of Modern Democratic and Dictatorial System. Hold Rinehart and Winston, New York.

\section{Newspapers and Magazines}

Tell, (Lagos).

Vanguard (Lagos).

Nigerian Tribune (Ibadan).

The Punch (Lagos).

Nigerian Compass (Isheri).

Newswatch, (Lagos). 